\title{
Rainbows amid Downpours: University Students' Goals in Learning English during Digital Experiments
}

\author{
Cathy Mae Dabi Toquero, Swen Joshryll C. Acebes, Jaizele B. Melitante \& Nikki T. Tuble \\ College of Education, Mindanao State University-General Santos City. Philippines \\ cathymaetoquero@gmail.com
}

\section{ARTICLE HISTORY \\ Received : 2021-05-30 Revised : 2021-08-10 \\ Accepted : 2021-08-19}

\section{KEYWORDS}

Online learning

COVID-19

Learning goals

Learning English

Higher education

Learning aspirations

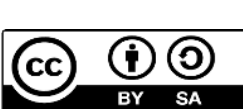

\begin{abstract}
University students are susceptible to the constantly shifting online milieu during the pandemic. Linguistic isolation can present more difficulties as students lack authentic social communication in classes online. This study examined the hopes and goals of university students in their English learning course during emergency remote learning. Third Year Pre-Service teachers of a state university in the Philippines served as participants in this study. Through content analysis of 28 student-responses of the English Modules, the research findings demonstrate the significance of hopes and goals of the university students in learning English during the pandemic. Amidst the digital experiments, students portray hopes and goals of developing their pedagogical skills in English and broadening their linguistic skills despite linguistic isolation. Students' goals in the course are to improve their language skills, develop in-depth knowledge in English, achieve better grades, and become effective potential teachers. As they aim to achieve those goals amid metaphorical downpours, university students reflect on the purpose of the course to equip them for lifelong learning that may develop ethical value, morality, and sense of vocation in their chosen profession. Despite having to confront the difficulties of learning online, their hopes and aspirations spark a burning desire to engage in intellectual and linguistic battles in learning English during pandemic and post-pandemic. Academic implications include for teachers to integrate authentic assessments for experiential language learning and for students to sketch a visual career plan outlining how students may achieve their goals as future educators.
\end{abstract}

\section{Introduction}

On March 11, 2020, the World Health Organization Director-General proclaimed SARSCoV-19, a novel coronavirus that causes COVID-19 infection, a pandemic, compelling the worldwide community to respond immediately (WHO, 2020). As a result, a pedagogical paradigm occurred, allowing for the online delivery of teaching and learning activities via Emergency Remote Teaching (ERT) methods (Hodges et al., 2020). Emergency Remote Teaching (ERT) is a temporary, short-term workaround for converting traditional courses to online learning platforms in the interest of conformance. It is not intended to be a long-term answer to developing higher education's online learning platforms (Nae, 2020). As a result, COVID19 presented numerous opportunities and challenges for educational institutions to strengthen their technical knowledge systems.

Additionally, the expansion of COVID-19 has compelled millions of students to switch to online communication. The government and policymakers have closed schools until further notice. As a result, students must adjust to a new normalcy. Although technological advancements have enabled many previously unthinkable feats, the transition to emergency learning has not been as seamless as students and teachers wish. Confronting the shortcomings of digital learning may be depressing and upsetting for teachers and students alike. As a result, the transition to ERT sparked worries among some students about equality and impediments. An individual's access to educational opportunities should have no bearing on situations outside their control (Salami and Bassett, 2014).

Similarly, Onyema et al. (2020) examined the impact of COVID-19 on education in several countries. They stated that many students use technology to complete their education during COVID-19. Compared to face-to-face instruction, this revolutionary shift to online learning amid pandemics continues to receive negative reviews as a poor or ineffective technique for accomplishing quality learning. 
About (2020) also discovered that e-learning affects both internal and external aspects affecting English language instructors, including "motivation, behaviors, responsibilities, and autonomy" (p. 26). Further, Before the pandemic, according to Forson and Vuopala's (2019) research, students' favored online teaching and learning over face-to-face training. Thus, the flexibility of the online option over the other has a positive effect on this choice.

However, as the pandemic arrived in 2020, enormous stress and difficulties are documented in recent research (Son et al., 2020; Toquero, 2020) concerning student experience in classes done virtually. Nonetheless, Kauffman (2015) mentioned that online classes provide convenience and flexibility that traditional face-to-face classes cannot, which is critical for learners during this time as they are juggling work, school, and family responsibilities. Almost all courses now include an online component, frequently utilising web-based technology to facilitate the distribution of course materials such as syllabi and assignments (e.g., Bozkurt et al., 2020; Allen \& Seaman, 2011). Researchers discovered that students who have more hope are more likely to have a successful job, stronger friendships, and increased creativity (Zakrzewski, 2012). Hence, students continue to discover silver linings in the challenges associated with remote learning. Moreover, students strive to persevere and demonstrate constructive behavior, reactions, and attitude to overcome the daily hurdles of remote learning, viewing education as a worldwide common good.

Indeed, the COVID-19 pandemic has accelerated and significantly altered the nature of schools and education (Vial, 2019). Additionally, the global pandemic of COVID-19 compelled higher education institutions throughout the United States to implement Emergency Remote Teaching (ERT), which required students and faculty to immediately adapt to a new form of teaching and learning (Gelles et al. 2020). Even if the pandemic instilled fear, students now require a sense of success regardless of the conditions. Thus, notwithstanding the disadvantages encountered by university students and the difficulties encountered during the move to a more current learning system, learning should continue.

Locally, Toquero (2021) asserted that the Philippines is unprepared to implement online schooling. Since many schools in the Philippines operated in a traditional classroom format before COVID-19, the government is currently striving to provide education through alternate delivery methods during this crisis. However, the time has come for the country's educational system to tackle its most difficult challenge to date: emergency remote education.

Taking a closer examination in the local context, the researchers examined how university students cope in a remote learning environment. This research study sought to examine university students' aspirations for English learning during Academic Year 2020-2021. The research study aimed to analyse the hopes and goals of the pre-service teachers in learning English during the digital experiments. For this reason, qualitative research was undertaken through a content analysis using the students' GED 113 Module Introduction in English.

Section 2 provides insight into the research methods in the research study, including the study participants - the research instrument employed, how researchers analyzed the data, and the data gathering procedure with its ethical considerations. Section 3 discusses the hopes of students in learning English and the goals of students in learning English. Section 4 discusses the study's findings and their importance in filling in the existing literature gap. Finally, Section 5 offers the conclusion of the paper with recommendations for future research. The paper is categorised hereafter.

\section{Method}

During the digital experiments, the researchers used a qualitative research approach to elicit information about the pre-service students' aims for learning the pedagogy of the English Language. The research endeavored to ascertain the students' intentions for English learning during modular education in emergency remote sessions through content analysis. Content analysis is a type of research approach used to elicit patterns from recorded speech. The researchers conducted content analysis by collecting data systematically from a collection of texts, which may be written, oral, or visual (Luo, 2019). Additionally, researchers employed content analysis to ascertain the presence, meanings, and linkages of particular words, topics, or concepts.

\subsection{Participants}

The participants in this study were pre-service teachers from Mindanao State University (MSU) in General Santos City. The participants comprised 28 pre-service students who were third-year pre-service teachers from the College of Education.

The participants came from one section, and the students' data selection was reliant on the voluntary submission of the Module Introduction. Ethical considerations were considered in the research methods and stages of this research study. The respondents voluntarily participated in this research endeavor, ensuring the respondents' identity be kept private, and only answers were used in this study.

The research took place at Mindanao State University in General Santos City, Philippines, located in the tuna capital of the Philippines. It is one of the best performing institutions in the country. The University is divided into seven colleges: the College of Agriculture, the College of Business and Accountancy, the College of Education, the College 
of Engineering, the College of Fisheries, the College of Natural Sciences and Mathematics, and the College of Social Sciences and Humanities.

\subsection{Research Instruments}

The researchers employed content analysis to interpret the pre-service teachers' opinions/views on goals in learning English during the digital experiments. The researchers utilized the GED 113 module under the course titled: "Teaching English in the Elementary Grades." Structured questions were utilized about the goals of the students in learning English during a pandemic.

\subsection{Data Gathering Procedure}

Ethical considerations are prioritized in the research stages of this endeavor. The respondents voluntarily participated in this research, ensuring the respondents' sensitive information with utmost confidentiality as only answers were used in this study. Additionally, no other details about the respondents' identity were revealed to avoid trampling on their privacy. The researchers utilised the GED 113 module and employed content data analysis. Due to the pandemic, third-year pre-service teachers volunteered to hand in their accomplished GED 113 module via the Telegram application.

In every learning endeavor, the outcomes are the most anticipated part. In the module, pre-service teachers were expected to investigate theories related to teaching English as a second language by analysing linguistics, psycholinguistics, and pedagogical approaches. Pre-service teachers should be able to distinguish beginning and intermediate students' language learning requirements and capabilities.

Furthermore, GED 113 focused on preparing preservice teachers to learn the children's grammar structure and fluency pedagogy and principles. The course is delivered using the English Language through listening, reading, writing, and speaking. The pre-service teachers can also investigate second language acquisition theories, pedagogical considerations, and language teaching methodologies associated with teaching English as a second language to improve the learners' communication skills. These theories are thoughts founded on principles and evidence in excelling at language learning. Moreover, through the module, students retain more information, mainly when applied to real-world tasks or problems. It allows the student to explore and be creative in learning.

The overall goal of the course is to help students build their future learners' language proficiency, gain an in-depth understanding of pedagogical principles in English, and improve their performance in English Language communication. Despite linguistic isolation, students portray hopes and goals to expand their English pedagogical skills and strengthen their linguistic skills. The difficulties that arise due to the current learning model and their hopes and dreams spark a burning desire to engage in intense discussions in the English language amid the event of a pandemic and post-pandemic.

\subsection{Data Analysis}

The researchers used student responses which were analyzed through document reviews to elucidate the notions behind the themes. Document analysis is a subset of qualitative research in which the researcher examines documents to give them a voice and meaning concerning a specific evaluative issue (Bowen, 2009).

Moreover, Module Content themes consisted of repeatable words that assisted the researchers to interpret the questions and ensuring that the comments are examined systematically according to content analysis principles. Thus, Bowen (2009) defines document analysis as a process of viewing documents to gather empirical data and increase comprehension.

Additionally, due to the numerous ways document analysis can aid and enrich research, critical points were painstakingly recorded. The researchers showed their findings with meticulous analysis. The researchers then documented the themes, codes, and classifications that emerged from the data. In Figure 2.1 shows three sample works that detail the hopes and goals of some pre-service teachers who voluntarily participated in this research endeavor.

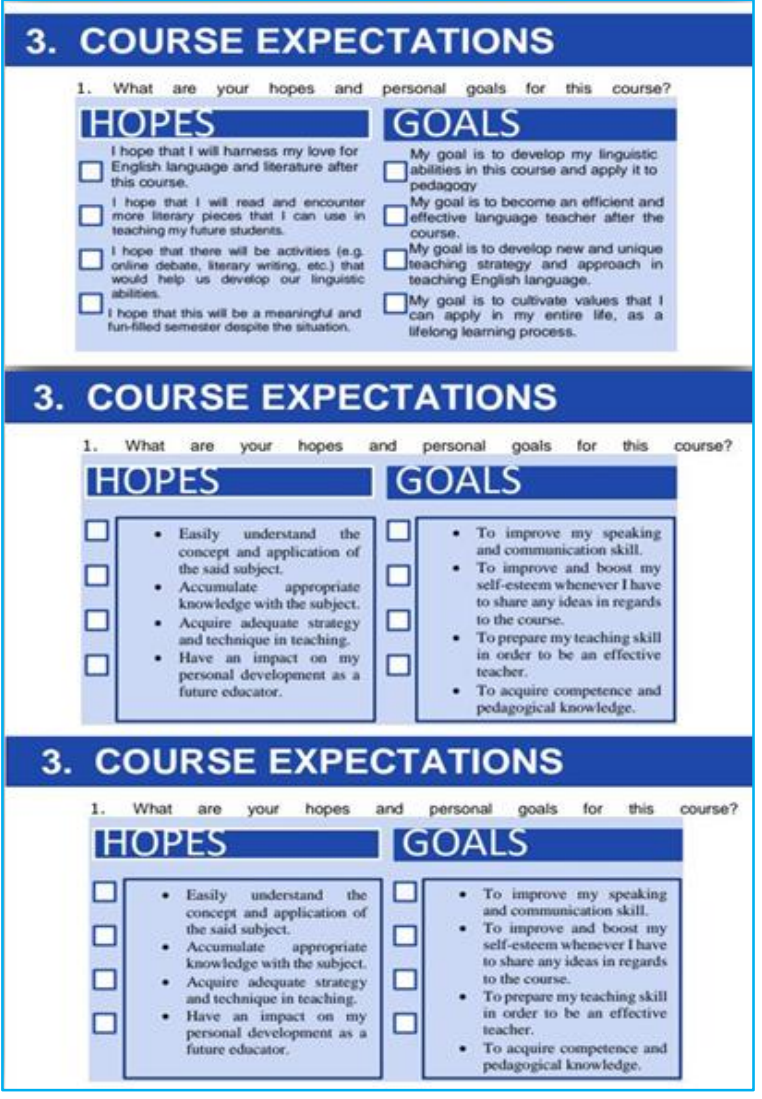

Figure 2.1. Pre-service Teachers' Hopes and Goals in Learning English during the pandemic 


\section{Findings}

The continuing public health crisis may lead to an increased career displacement and broadened success gaps among university students. Moreover, with the introduction of COVID-19, the education standard places an unsustainable environment that confronts the educational systems at risk. Nonetheless, the students' hopes in learning English during the pandemic (Table 3.1) show that they are eager to learn in the new delivery of instruction.

Apply knowledge and skills. Out of 28 students, the results show that 27 students hope to apply the knowledge and skills they can acquire from the English course. Students are hopeful of acquiring learning despite the challenges that they face in online environments. Student 12, for example, hopes that the "course can be a big opportunity to improve" to improve her "communicative language skills and literacy in the English Language."

Become an effective teacher. It can be observed from the result that the pre-service teachers under the English subject are adamant about becoming effective future educators. (Student 1: I am hoping that I will become an effective teacher after taking this course subject, especially in teaching English to the learners as their second language). The students want to gain adequate strategies and techniques in teaching their students in the future. Despite the limitations to actual learning experiences, the students believe that the English course can give an immense opportunity for learning during the pandemic.

Table 3.1. Content Analysis of Hopes of Students in learning English during the pandemic

\begin{tabular}{|c|c|c|c|c|c|}
\hline & Category & Descriptive Codes & Specific Examples & Frequency & $\%$ \\
\hline \multirow{6}{*}{$\begin{array}{c}\text { Hopes of } \\
\text { students in } \\
\text { learning } \\
\text { English } \\
\text { during } \\
\text { COVID- } \\
19\end{array}$} & $\begin{array}{l}\text { Apply } \\
\text { knowledge } \\
\text { and skills }\end{array}$ & $\begin{array}{l}\text { Communicative } \\
\text { language and } \\
\text { literacy }\end{array}$ & $\begin{array}{l}\text { Develop my English language skills } \\
\text { Accumulate appropriate knowledge of the subject. } \\
\text { Acquire adequate strategy and technique in teaching. }\end{array}$ & 27 & $96 \%$ \\
\hline & $\begin{array}{l}\text { Become an } \\
\text { Effective } \\
\text { Teacher }\end{array}$ & $\begin{array}{l}\text { Effective } \\
\text { pedagogy }\end{array}$ & $\begin{array}{l}\text { I hope that this course can build me to become a } \\
\text { successful English teacher someday. } \\
\text { I hope that I can learn new and some fresh ideas to } \\
\text { teach effectively to my students someday if I will } \\
\text { become an educator. } \\
\text { I hope that we can use the topics, approaches and } \\
\text { methods in teaching when we are in the field. }\end{array}$ & tons & $64 \%$ \\
\hline & $\begin{array}{l}\text { Experience } \\
\text { engaging } \\
\text { activities }\end{array}$ & $\begin{array}{l}\text { Fun learning } \\
\text { experience }\end{array}$ & $\begin{array}{l}\text { I hope that activities (e.g. online debate, literary } \\
\text { writing, etc.) will help us develop our linguistic } \\
\text { abilities. } \\
\text { I hope that this will be a meaningful and fun-filled } \\
\text { semester despite the situation } \\
\text { I hope that I will read and encounter more literary } \\
\text { pieces that I can use in teaching my future } \\
\text { students. }\end{array}$ & 13 & $46 \%$ \\
\hline & $\begin{array}{l}\text { Successful } \\
\text { lesson delivery }\end{array}$ & $\begin{array}{l}\text { Convenient \& } \\
\text { easy lessons }\end{array}$ & $\begin{array}{l}\text { I hope that learning this course would be easy for } \\
\text { me. } \\
\text { I hope that this course may not be too hard for } \\
\text { online learners }\end{array}$ & 8 & $29 \%$ \\
\hline & $\begin{array}{l}\text { Understanding } \\
\text { teachers }\end{array}$ & $\begin{array}{l}\text { Considerate } \\
\text { teachers }\end{array}$ & $\begin{array}{l}\text { I do hope that our instructor can be flexible and } \\
\text { considerate to her students } \\
\text { I hope that the teacher may be more considerate, } \\
\text { especially in giving complex tasks and setting } \\
\text { deadlines. }\end{array}$ & 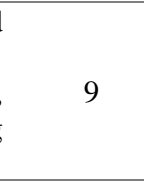 & $32 \%$ \\
\hline & $\begin{array}{l}\text { Personal } \\
\text { growth }\end{array}$ & $\begin{array}{l}\text { Confidence \& } \\
\text { positivity }\end{array}$ & $\begin{array}{l}\text { I hope that I will harness my love for the English } \\
\text { language and literature after this course. } \\
\text { Accumulate appropriate self-esteem whenever I know } \\
\text { the subject. to share any ideas in regards }\end{array}$ & (1) & $21 \%$ \\
\hline
\end{tabular}

Experience engaging activities. At the same time, it is a continuous challenge for the teachers to engage the students in the classes online. The students themselves are hopeful that they can experience enjoyable and meaningful activities in learning English during the pandemic. Student 16 mentioned that she wants to experience a "series of fun and datafriendly activities." The student echoed such sentiment since she, including some concerns of the students, has limited load allowance for internet surfing.

Consequently, the teachers need to provide language activities that can engage the students in their classes while not neglecting the concerns of the students who do not have regular internet connections.

Successful Lesson Delivery. The students emphasised the essential information they can obtain from the course and hoped for convenience and 
comfort in their learning experiences in the online classes. Student 16 argued that their teachers should not give "too much school works." Such sentiment stems from the subject overload and the bombardment of modules per subject every week or two for the entire semester.

Understanding Teachers. Some students hope for considerate and empathetic teachers to understand their situation. (Student 23: May the teacher be understanding in dealing with learners who have problems connecting to virtual classes.).
Personal Growth. Students are optimistic about the course, and a few emphasised their hopes to gain wisdom and values in learning English. Student 7 said that she hopes that the English course can motivate her to become an effective student.

English and are looking forward to a free pandemic future (Table 3.2). The students under this study experienced unique circumstances since they dealt with hiatus in their learning during the onset of the pandemic. However, they have goals that keep them going in their classes online.

Table 3.2. Content Analysis of Goals of Students in learning English for post-pandemic

\begin{tabular}{|c|c|c|c|c|c|}
\hline & Category & Descriptive Codes & Specific Examples & Frequency & $\%$ \\
\hline \multirow{6}{*}{$\begin{array}{l}\text { Goals of } \\
\text { students in } \\
\text { learning } \\
\text { English } \\
\text { during the } \\
\text { pandemic }\end{array}$} & $\begin{array}{l}\text { Expand } \\
\text { English } \\
\text { Language } \\
\text { Competence }\end{array}$ & $\begin{array}{l}\text { Knowledge and } \\
\text { skills }\end{array}$ & $\begin{array}{l}\text { To develop more understanding about teaching } \\
\text { English in elementary grades. } \\
\text { My goal is to expand my vocabulary about the } \\
\text { English language }\end{array}$ & 24 & $86 \%$ \\
\hline & $\begin{array}{l}\text { Effective } \\
\text { Pedagogical } \\
\text { Mastery }\end{array}$ & $\begin{array}{l}\text { Strategies and } \\
\text { methods }\end{array}$ & $\begin{array}{l}\text { My goal is to learn effective strategies in teaching } \\
\text { English. } \\
\text { My goal is to develop a new and unique teaching } \\
\text { strategy and approach in teaching the English } \\
\text { language. }\end{array}$ & 6 & $21 \%$ \\
\hline & $\begin{array}{l}\text { Gain In- } \\
\text { depth } \\
\text { knowledge }\end{array}$ & $\begin{array}{l}\text { Gain more } \\
\text { knowledge }\end{array}$ & $\begin{array}{l}\text { My goal is to finish this course with a lot of } \\
\text { knowledge acquired that can really help me in } \\
\text { teaching someday } \\
\text { My ultimate goal is to learn something new. } \\
\text { Something that has never been taught before. }\end{array}$ & 17 & $61 \%$ \\
\hline & $\begin{array}{l}\text { Effective } \\
\text { Future } \\
\text { Teachers }\end{array}$ & $\begin{array}{l}\text { Efficient } \\
\text { educator }\end{array}$ & $\begin{array}{l}\text { To be an effective English teacher after taking } \\
\text { this subject } \\
\text { My goal is to become an efficient and effective } \\
\text { language teacher after the course. }\end{array}$ & 10 & $36 \%$ \\
\hline & $\begin{array}{l}\text { Achieve } \\
\text { Better } \\
\text { Grades }\end{array}$ & High remarks & $\begin{array}{l}\text { My goal is I pass this subject and get a good grade } \\
\text { Stay motivated and achieve my goal, which is to } \\
\text { have high grades in this course. }\end{array}$ & 15 & $54 \%$ \\
\hline & $\begin{array}{l}\text { Reflect } \\
\text { one's } \\
\text { becoming }\end{array}$ & Instil values & $\begin{array}{l}\text { To develop moral imagination, ethical values, and a } \\
\text { sense of vocation } \\
\text { My goal is to cultivate values that I can apply in my } \\
\text { entire life as a lifelong learning process. }\end{array}$ & 11 & $39 \%$ \\
\hline
\end{tabular}

Expand English Language Competence. The students shared their goals of acquiring pedagogical knowledge and skills. (Student 7: To gain much information on this subject to be aware, especially of what happened right now in our society). They look forward to a future that can maximise the opportunity for their future learners to create a better world.

Effective Pedagogical Mastery. Only 6 out of the 28 students have made the goal of attaining English teaching mastery their entire focus. (Student 9: My goal is to learn effective strategies in teaching English). Students want to become better at strategies and approaches that will aid them in delivering quality learning in the teaching environment. This mastery will assist each student in developing their algorithm for learning English and devising a personal strategy for mastering the target language's knowledge.

Gain In-depth Knowledge. Learning English is exciting for the students since they want to experience authentic learning activities and gain a deeper knowledge of the English pedagogy. The students aim to develop higher-order thinking skills to teach in a meaningful way for their future learners.

Effective Future Teacher. A significant number of students have aspired to become effective teachers by imparting knowledge to future English learners. (Student 10: To be an effective English teacher after taking this subject). They want to become effective teachers, so after taking this course subject and learning pedagogical knowledge and skills, they are adamant that they can be fully equipped as English teachers. The skills needed for effective teaching involve more than just expertise in the academic field. This will bring ways to teach effectively and understand a new way of looking at the world.

Achieve Better Grades. Half of the participants wish to improve their grades because they have completed all required activities for the course material. (Student 25: Stay motivated and achieve my goal, which is to have high grades in this course). 
Regardless of how students' learning style changes, achieving a higher grade is always a goal. Students strive to improve their performance in the English academic field because it is significant for acquiring recognition.

Reflect One's Becoming. 11 students out of 28 are motivated to develop moral values as they learn English principles and processes. (Student 18: To develop moral imagination, ethical values, and a sense of vocation). Fewer students have significant reasons to believe in their ability to develop moral character through learning English. They reflect on their lives, behaviors, and beliefs. This is increasingly believed to be critical in teaching students academic concepts and assisting them in taking appropriate actions for a better world.

\section{Discussion}

This research analyzed the university students' goals in their English learning during the pandemic relative to emergency remote learning. Students' hopes and ambitions spark the heart-burning fire of learning to undertake this scholarly effort in silent battles.

One of the English requirements for these university students is to develop their English communication abilities. Walqui et al. (2018) said unequivocally that oral language development is vital for all English learner educational programs. It promotes the possibility of collaborative learning activities and positive speaking. As university students desire to become competent teachers in their field, they wish to improve their future learners' English language proficiency by learning more about teaching strategies in Teaching English to Elementary Graders. Students comprehend how learning English may help them create a better world in their future activities. Thus, university students must employ various learning and cognitive strategies to practice their English language skills (Bifuh-Ambe, 2011).

Universities can increase the amount of studying time to provide English Learners with language and academic enrichment opportunities. However, the lack of motivating participation in remote virtual orders (Aboagye et al., 2020) and social interactions with peers and teachers in an online world prevents university students from reaching their aspirations. As a result, during the COVID-19 pandemic, peer approaches seem promising to the capability of the students to learn English. According to a comprehensive meta-analysis conducted by Huang et al. (2018), peer-support interventions demonstrated the most significant impact for preventing depression and generalised anxiety disorder amongst college students compared with other group approaches.

Based on the study's findings, students expect considerate and empathetic teachers to understand their situation when dealing with problems in virtual classes. Due to subject overload and the bombardment of modules per subject every week or two in an entire semester, university students find it challenging to handle the classes, which adds to their already existing household difficulties. As a result, the university students clamour the teacher's understanding for better and improved English language acquisition. According to Samson and Collins (2012), teachers who are aware of and appreciate these distinctions can better respond in ways that foster a reciprocal learning environment.

Furthermore, as pre-service teachers, they plan to gain an in-depth knowledge of English teaching methods and techniques to do an excellent job teaching English to young students in the future. This is why they need to see the link between education theory and practice; hence, students will be able to witness how teachers employ practices to adapt to the different needs of K-12 students (Sevimli-Celik, 2020). The content knowledge of pre-service teachers affects how they interpret the content goals they expect to achieve in their course learning (Kang \& Kline, 2020). The focus should be on professional development since they need to do better and raise their academic performance standards.

To meet the challenging demands, pre-service teachers must be capable and willing to continually upgrade their content knowledge, skills, and practices (Ayeni, 2011). On the other hand, the students' encountered distance learning difficulties since many of them cannot manage their time effectively during their classes online. Students find it challenging to balance their time from studying and doing extra work in their homes. Thus, according to Sari and Megayanti (2021), students depended merely on their discipline in controlling their learning time at home to continue their distance learning. Theoretically, the variable of time management has direct influence on students learning outcomes. A strong emphasis on effective and efficient time management has also been identified as a critical component of success (Nasrullah \& Khan, 2015). To conduct distance education, students relied totally on their discipline in regulating their academic time at home, where they practiced controlling their educational time independently in their personal space (Sari, \& Megayanti, 2021). When this aspect of time management is neglected during emergency remote learning, negative consequences for learning outcomes are unavoidable, most notably for university students' ability to learn English for future pursuits. Additionally, Farbman (2015) proposes that English learners should use this effort to concentrate on linguistic enrichment and to acquire lacking academic materials.

Additionally, students needed to be better informed to deal with the pandemic's effects and polymers with courses and skills across the board to meet their English language learning objectives. 
Lemberger and Clemens (2012) highlight that a program aimed at assisting students with their histories can substantially impact students' progress in learning English, as they feel included, healthy, and supported. Thus, maintaining interaction between students can foster an enthusiasm for learning and progress, which is necessary for efficient and fruitful online English study. In any case, it would be preferable to give secure, temporary, effective, and continued access to quality education during a crisis than to reconfigure a sophisticated education environment to accommodate urgent and high-priority English learners. The English subject demands participatory teaching approaches that motivate and empower learners to make positive behavioural changes and contribute to sustainable development. As a result, education for sustainable development encourages the development of abilities such as critical thinking, scenario planning, and collaborative decision-making (Kioupi \& Voulvoulis, 2019).

One of the study's findings shows that university students desire a dynamic and engaging activity that would enhance their learning experience while also navigating their attention during a pandemic. Students must be involved and accountable for their educational achievement, allowing students to participate actively and be accountable for their educational success (Ciobanu, 2018). The support for their development may allow them to gain some wisdom despite their shortcomings. Coping styles are observed in response to substantial trauma or hardship, and these are necessary for the process of discovery. Self-related benefits include developing an attitude of gratitude, experiencing unanticipated personal growth, and gaining new clarity about the future (August \& Daapkewicz, 2021). Hence, learning English necessitates participatory teaching and learning methods that motivate and empower learners to support sustainable development.

Despite their dedication to the English course during a pandemic, students' performance in learning English have been significantly hampered by a lack of opportunity. Likewise, despite many instructors' valiant efforts to ensure their students' access to education during school closures, existing weaknesses in the school structure have been highlighted, such as a widespread shortage of financial resources. While faculty members transitioned to ERT as quickly as possible, students encountered comparable difficulties. Certain students lack access to resources such as computers, webcams, and a secure Internet connection (Neuwirth et al., 2020). In addition, despite the shared joy of implementing online language instruction on short notice as a response to the pandemic, this transition in teaching delivery configuration has presented a number of challenges to language educators and administrators in both English as a Second Language (ESL) and English as a Foreign Language (EFL) contexts (Chung \& Choi, 2021) that may affect students' learning performance. Hence, sustainability in education highlights the necessity of innovative and sustainable educational techniques. It also encourages teaching, learning, and assessment strategies that enable students to build the skills and confidence necessary to be successful lifelong learners (Blewitt, 2004).

Thus, Adedoyin \& Soykan (2020) indicated that one of the issues students experience during this pandemic is accessibility. In other words, students who do not possess the means necessary to access broadband are the most underprivileged, as this is the primary reason for their lack of English language learning. Lack of access to fast, affordable, and dependable connection speeds hampers online learning, particularly for rural and vulnerable people in Pakistan (Wains \& Mahmood, 2008). Students who access the web via their cellphones cannot participate in online classes since a big chunk of online content is unavailable to them. Students' social marginalisation, as a result of limited internet quality and utilisation, and a shortage of cutting-edge technology, had an adverse effect on organisational response and students' capability to partake in digital learning (Zhong, 2020).

Nonetheless, despite their academic difficulties, university students can excel in English when teachers consider their students' social hopes and educational goals. Hope enables students to keep going (Britzman, 2021). As a result, students must take ownership of their learning, as this is one of the trademarks of more substantial knowledge.

\section{Conclusion}

In conclusion, the research findings indicate a significant notion on university students' attitudes about English learning during the epidemic. The findings about university students' aspirations demonstrate how learning English can prepare them to be effective teachers in their future undertakings and supplement their personal development as practical students. Their hopes also partake in the ongoing delivery of Emergency Remote Learning. An empathetic teacher can assist them in using their obtained knowledge and abilities to improve their communicative language skills and literacy in the English language. University students' aim to widen their English Language competencies, gain in-depth knowledge about it, and learn various and innovative learning strategies that they can apply in their future teaching. Students also aspire to improve their grades to become an effective future educator. Likewise, university students' English learning enables them to reflect on their personal development to build ethical value, morality, and the sense of mission that they have chosen to pursue.

This study has its limitations, particularly in qualitative writing, since interviews may have provided better results to support the study. 
Quantitative data may also yield better results when complemented with the interviews. Nevertheless, the result offers educational value. Teachers should employ authentic assessments to their learners during synchronous classes, primarily focusing on speaking and writing tasks to help the students develop their English communication skills. Additionally, the students should experience various English techniques and strategies that they can use in their future classroom instruction. Finally, to ensure adequate English language learning, teachers should encourage the university students to sketch a visual career plan outlining how they may achieve their goals as future educators despite the abrupt shift in course learning during the pandemic.

\section{References}

Aboud, F. (2020). The effect of E: Learning on EFL teacher identity. International Journal of English Research, 6(2), 22-27.

Adedoyin, O. B., \& Soykan, E. (2020). Covid-19 pandemic and online learning: the challenges and opportunities. Interactive Learning Environments, 1-13. https://doi.org/10.1080/10494820.2020.181318 0

Allen, I. E., \& Seaman, J. (2011). Going the distance: Online education in the United States, 2011. Sloan Consortium.

Arenas, D. L., Viduani, A. C., Bassols, A. M. S., \& Hauck, S. (2021). Peer support intervention as a tool to address college students' mental health amidst the COVID-19 pandemic. International Journal of Social Psychiatry, 67(3), 301-302.

August, D. (2018). Educating English Language Learners: A Review of the Latest Research. American Educator, 42(3), 4-39

August, R., \& Dapkewicz, A. (2021). Benefit finding in the COVID-19 pandemic: College students' positive coping strategies. Journal of Positive School Psychology, 5(2), 73-86.

Ayeni, A. J. (2011). Teachers' Professional Development and Quality Assurance in Nigerian Secondary Schools. World Journal of Education, 1(1), 143-149.

Bifuh-Ambe, E. (2011). Postsecondary learning: Recognizing the needs of English language learners in mainstream university classrooms. Multicultural Education, 19(3), 1319.

Blewitt, J. (2004). Sustainability and lifelong learning. In The Sustainability Curriculum: The Challenge for Higher Education; Earthscan: London, UK; pp. 24-42.

Bowen, G. A. (2009). Document analysis as a qualitative research method. Qualitative
Research Journal, 9(2), 27-40. https://doi.org/10.3316/QRJ0902027.

Bozkurt, A., \& Sharma, R. C. (2020). Emergency remote teaching in a time of global crisis due to CoronaVirus pandemic. Asian Journal of Distance Education, 15(1), i-vi.

Britzman, D. (2021). Anticipating Education: Concepts for Imagining Pedagogy with Psychoanalysis. Stylus Publishing, LLC.

Chung, S. J., \& Choi, L. J. (2021). The Development of Sustainable Assessment during the COVID19 Pandemic: The Case of the English Language Program in South Korea. Sustainability, 13(8), 44-99. https://doi.org/10.3390/su13084499.

Ciobanu, N. R. (2018). Active and participatory teaching methods. European Journal o Education, 1(2), 69-72.

Ferri, F., Grifoni, P., \& Guzzo, T. (2020). Online learning and emergency remote teaching: Opportunities and challenges in emergency situations. Societies, 10(4), 1-18

Farbman, D. (2015). Giving English Language Learners the Time They Need to Succeed: Profiles of Three Expanded Learning Time Schools. Boston: National Center on Time and Learning.

Forson, I. K., \& Vuopala, E. (2019). Online learning readiness: perspective of students enrolled in distance education in Ghana. The Online Journal of Distance Education and $e$ Learning, 7(4), 277-294.

Gelles, L. A., Lord, S. M., Hoople, G. D., Chen, D. A., \& Mejia, J. A. (2020). Compassionate flexibility and self-discipline: Student adaptation to emergency remote teaching in an integrated engineering energy course during COVID-19. Education Sciences, 10(11), 304.

Hodges, C., Moore, S., Lockee, B., Trust, T., \& Bond, A. (2020). The difference between emergency remote teaching and online learning. Educause Review, 27(1), 1-9.

Huang, J., Nigatu, Y. T., Smail-Crevier, R., Zhang, X., \& Wang, J. (2018). Interventions for common mental health problems among university and college students: A systematic review and meta-analysis of randomised controlled trials. Journal of Psychiatric Research, 107(2018), 110.

Kang, G., \& Kline, S. (2020). Critical Literacy as a Tool for Social Change: Negotiating Tensions in a Pre-Service Teacher Education Writing Course. Journal of Language and Literacy Education, 16(2), 1-16.

Karataş, T. Ö., \& Tuncer, H. (2020). Sustaining Language Skills Development of Pre-Service EFL Teachers despite the COVID-19 
Interruption: A Case of Emergency Distance Education. Sustainability, 12(19), 81-88.

Kauffman, H. (2015). A review of predictive factors of student success in and satisfaction with online learning. Research in Learning Technology, 23, 1-11.

Kioupi, V., \& Voulvoulis, N. (2019). Education for sustainable development: A systemic framework for connecting the SDGs to educational outcomes. Sustainability, 11(21), 2-18. https://doi.org/10.3390/su11216104

Lawrence, J. (2012). "English Vocabulary Trajectories of Students Whose Parents Speak a Language Other Than English: Steep Trajectories and Sharp Summer Setback," Reading and Writing: An Interdisciplinary Journal, 25(5), 13-41.

Luo, A. (2019). Content Analysis: A Step-by-Step Guide with Examples. Scribbr. https://www.scribbr.com/methodology/ Content Analysis:-A-Step-by-Step-Guide-withExamples

Nae, N. (2020). Conventional Education vs. Remote Education - "Just Put it Online?" A Report from Japan. 13th International Conference Innovation in Language Learning -Virtual Edition, 204-207.

Nasrullah, S., \& Khan, M. S. (2015). The impact of time management on the students' academic achievements. Journal of Literature, Languages and Linguistics, 11(2015), 66-71.

Neuwirth, L. S., Jović, S., \& Mukherji, B. R. (2020). Reimagining higher education during and postCOVID-19: Challenges and opportunities. Journal of Adult and Continuing Education, $\quad 0(0), \quad 1-16$. https://doi.org/10.1177/1477971420947738

Onyema, E. M., Eucheria, N. C., Obafemi, F. A., Sen, S., Atonye, F. G., Sharma, A., \& Alsayed, A. O. (2020). Impact of Coronavirus pandemic on education. Journal of Education and Practice, 11(13), 108-121.

Salami, J., \& Bassett, R.M. (2014), —The equity imperative in tertiary education: promoting fairness and efficiencyll, International Review of Education, 60(3), 361-377, https://doi.org/10.1007/s11159-013-9391-z.

Samson, J. F., \& Collins, B. A. (2012). Preparing All Teachers to Meet the Needs of English Language Learners: Applying Research to Policy and Practice for Teacher Effectiveness. Center for American Progress.

Sari, M., \& Megayanti, T. (2021). Time Management During Covid-19 Pandemic: The Effect of Students' Time Management on Learning Outcomes in Basic Building Construction Course at State Vocational High School 5
Bandung, West Java, Indonesia.6th UPI International Conference on TVET 2020 (TVET 2020), 520, 36-39.

Sevimli-Celik, S. (2020). Moving between theory and practice: preparing early childhood pre-service teachers for teaching physical education. Journal of Early Childhood Teacher Education, 1-18, https://doi.org/ 10.1080/10901027.2020.1735588.

Son, C., Hegde, S., Smith, A., Wang, X., \& Sasangohar, F. (2020). Effects of COVID-19 on college students' mental health in the United States: Interview survey study. Journal of medical internet research, 22(9), 1-22.

Sugarman, J., \& Lazarín, M. (2020). Educating English Learners during the COVID-19 Pandemic: Policy Ideas for States and School Districts. Policy Brief. Migration Policy Institute

Toquero, C. M. D. (2020). Will COVID-19 Bring the Armageddon? Expanding Psychosocial Support and Environmental Care: An Autoethnographic Research. Aquademia, 4(2), ep20022. https://doi.org/10.29333/aquademia/8438

Toquero, C. M. (2021). Emergency remote education experiment amid COVID-19 pandemic. IJERI: International Journal of Educational Research and Innovation, (15), 162-176. https://doi.org/10.46661/ijeri.5113

Vial, G. (2019). Understanding digital transformation: A review and a research agenda. The journal of strategic information systems, 28(2), 118-144.

Wains, S. I., \& Mahmood, W. (2008). Integrating mlearning with e-learning. In Proceedings of the 9th ACM SIGITE Conference on Information Technology Education. 31-38.

Walqui, A., \& Heritage, M. (2018). "Supporting English Learner' Oral Language Development," American Educator, 42(3), 18-23

World Health Organization (WHO) (2020), "WHO Director-General's opening remarks at the media briefing on COVID-19 - 11 March 2020". www.who.int/dg/speeches/detail/whodirector-general-s-opening-remarks-at-themedia-briefing-on-covid-19-11-march-2020

Zakrzewski, V. (2012). How to help students develop hope. Greater Good: The Science of a Meaningful Life, 1-2.

Zhong, R. (2020, March 17). The coronavirus exposes education's digital divide. The New York Times, 18.

https://www.nytimes.com/2020/03/17/technolo gy/china-schools-coronavirus.html 